\title{
Research on Enterprise Knowledge Management Based on SECI-Clouds Model
}

\author{
Hu Jixi \\ Pingxiang University, Pingxiang, Jiangxi, 337055, China
}

Keywords: knowledge management; knowledge creation and conversion mechanism; the SECI-Clouds model; enterprise development

\begin{abstract}
In today's economic and service development, enterprises are faced with the challenges to establish a long-term knowledge vision and to provide an effective knowledge management platform. The establishment of members of the supervision and incentive mechanism is urgently needed. The fundamental task of the enterprise lies in the creation of knowledge. The members of the enterprise have established the concept of full learning, which has opened up their horizons. It has paid close attention to the knowledge management both inside and outside the enterprise. As a result, enterprises can continue to create new knowledge in the long-term competitive advantage.
\end{abstract}

\section{Introduction}

With the development of information and communication technology, the world economy is affected from the industrial economy to the knowledge economy transition and knowledge has been considered to improve labor productivity as economic growth promoters. Knowledge management is the corresponding new economic era of emerging management ideas and methods. It is through knowledge sharing and the use of collective wisdom to improve the organization's response. The purpose is to achieve the display of knowledge and tacit knowledge sharing to provide a management approach.

The purpose of knowledge management is to establish a mechanism to motivate employees to participate in knowledge and develop enterprise innovation. Enterprise innovation from the surface is a collection of a single event. In fact, this collection has been accompanied by the flow of knowledge. Because the process of innovation is the relevant knowledge acquisition, the enterprise's innovation process and knowledge management are closely related. Knowledge management is the basis and protection of efficient innovation.

\section{Classification and Transformation of Knowledge}

Knowledge transformation is a process of the self-transformation in intellectual capital within the same state. Knowledge transformation is the core of knowledge management in the object of close attention to knowledge management practice. Therefore, knowledge transformation is the research topic of knowledge management research field [1]. To some extent, we can consider that the transformation of knowledge to achieve the main function of knowledge management enhances the efficiency of knowledge management. It even determines the success or failure of knowledge management.

\section{Model description}

In knowledge management activities, knowledge transformation is not only the beginning of primary knowledge management activities, but also the starting point of advanced knowledge management activities [2]. It is a convergence point of junior knowledge management activities to advanced knowledge management activities. In other words, knowledge transformation is the goal of knowledge management activities such as knowledge collection, knowledge filtering, knowledge classification, knowledge storage and so on. It is also a platform for high-level knowledge management activities. 
In the process of knowledge transformation, the knowledge capital of the organization realizes the accumulation and quality improvement of the knowledge. The strategy of knowledge management is optimized constantly and the level of knowledge management is continuously improved. The capital function of knowledge is expanding constantly so that knowledge management objectives can be successfully achieved [3]. According to the connotation of knowledge theory in the practice of knowledge management, knowledge transformation is the key function of the enterprise core competence, which is an important way to cultivate the core competitiveness of enterprises, as is shown in Figure 1.

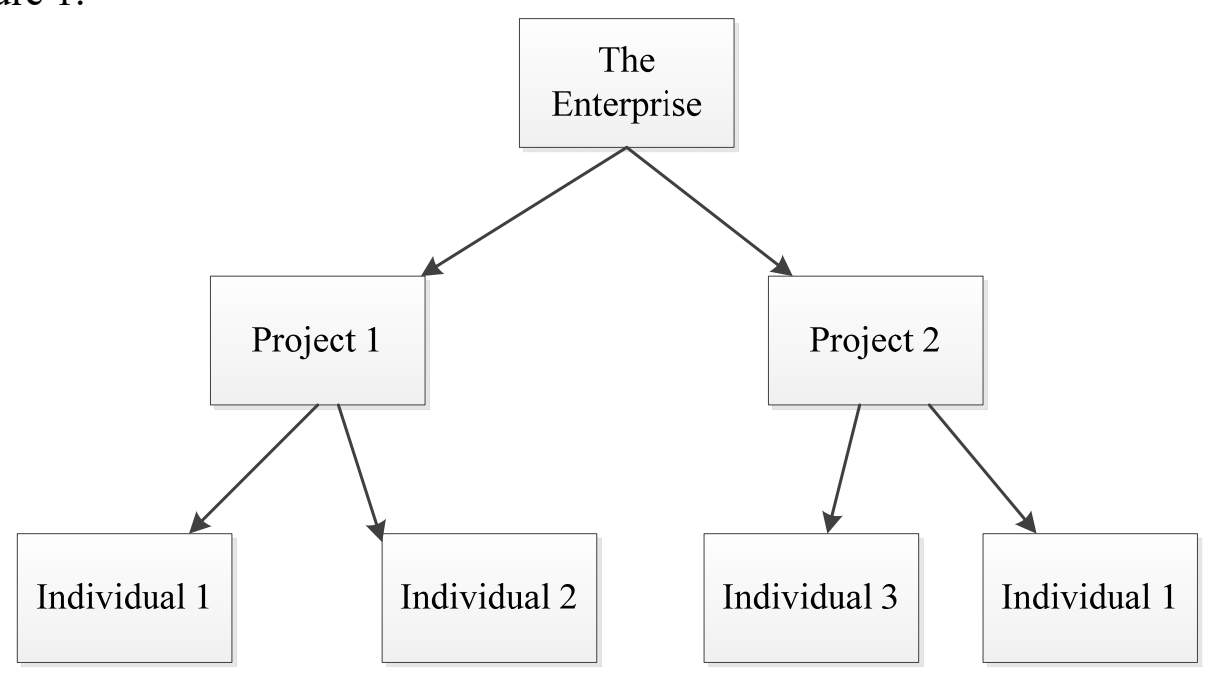

Figure 1. The solving process of SECI model

\section{Model solution}

According to the SECI Model in the field, the management consulting firms are faced with four problems in the transformation of tacit knowledge, which will be described as follows. The SECI Model states that people who have special knowledge are grouped together to achieve tacit knowledge management through a variety of tools. It allows the team members to interact and facilitate the transformation of tacit knowledge [4]. The theoretical premise is that the group members have the will to contribute to the hidden knowledge. Otherwise, tacit knowledge cannot be transformed into explicit knowledge.

\section{Analysis of Knowledge Management Based on SECI Model}

\section{Analysis on tacit knowledge table}

Each management consultant has its own set of methods and logic to perceive the situation, which became its core competitiveness [5]. If they have a set of methods to contribute, the existence of competitive business colleagues is the most unfavorable choice [6]. Therefore, the management consultants will choose to hide their knowledge as much as possible and the consulting firm is also difficult to obtain the tacit knowledge of employees. The relative models are shown in Table 1 below. 
Table 1. The subject level of enterprise knowledge management system

\begin{tabular}{|c|l|l|l|}
\hline $\begin{array}{l}\text { Knowledge } \\
\text { individuals }\end{array}$ & level of service & $\begin{array}{l}\text { Introduction of work } \\
\text { contents }\end{array}$ & $\begin{array}{l}\text { Initial knowledge } \\
\text { situations }\end{array}$ \\
\hline A & Individual & $\begin{array}{l}\text { Finished the operations of the } \\
\text { process a1 }\end{array}$ & $\begin{array}{l}\text { A has tacit knowledge } \\
\text { about work }\end{array}$ \\
\hline B & Individual & $\begin{array}{l}\text { Finished the operations of the } \\
\text { process a1 }\end{array}$ & none \\
\hline C & Individual & $\begin{array}{l}\text { Finished the operations of the } \\
\text { process a2 }\end{array}$ & $\begin{array}{l}\text { C has tacit knowledge } \\
\text { about work }\end{array}$ \\
\hline D & Individual & $\begin{array}{l}\text { Finished the operations of the } \\
\text { process a2 }\end{array}$ & None \\
\hline E & Project & $\begin{array}{l}\text { managed the knowledge of } \\
\text { project A }\end{array}$ & none \\
\hline F & Project & $\begin{array}{l}\text { managed the knowledge of } \\
\text { project A }\end{array}$ & none \\
\hline G & Corporate & $\begin{array}{l}\text { managed the knowledge of } \\
\text { the whole corporation }\end{array}$ & none \\
\hline
\end{tabular}

Since most employees are not willing to contribute to personal knowledge [7], they are forced to require staff to provide advisory project reports and to promote the transformation of tacit knowledge[8]. Even so, many employees on the various reports submitted to the large-scale changes are leading to the company's management. Hidden knowledge is almost in a state of stagnation.

\section{SECI model of explicit knowledge connection}

The advantage of explicit knowledge connection is that the integration of fragmented knowledge contribute to the knowledge of the heritage and learning. Management consulting firms usually set up knowledge and information departments [9], which are responsible for the company's knowledge management. The mechanism is vividly displayed in Figure 2.

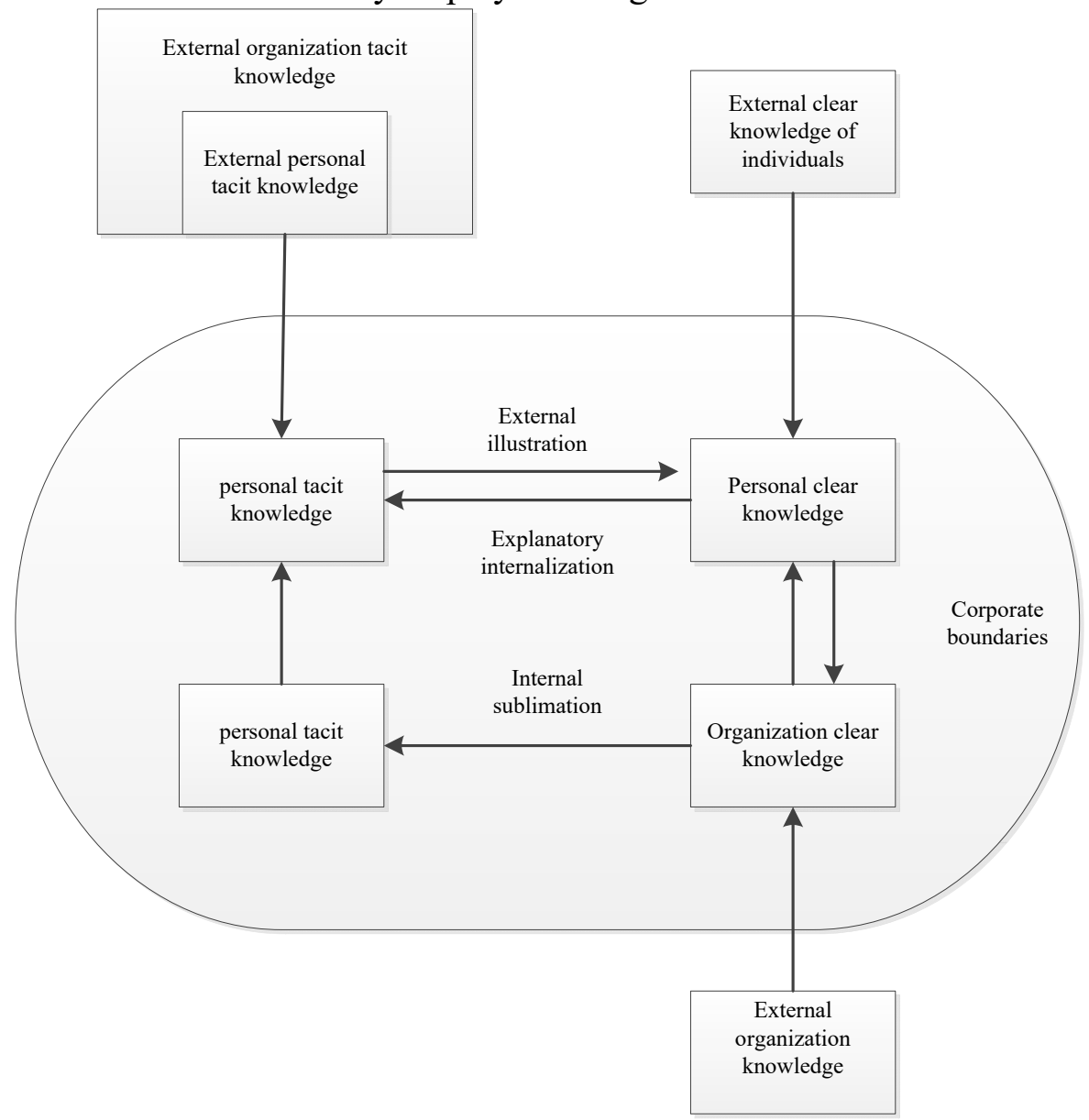

Figure 2. Mechanism of Knowledge Management Model 
However, there is still a problem with explicit knowledge linking. It is mainly because employees are reluctant to contribute their own tacit knowledge in the process of tacit knowledge. Out of the company's requirements [10], employees may provide a lot of useless knowledge to cope with and thus cannot form a scientific knowledge system, resulting in the connection of explicit knowledge of the difficulties.

\section{SECI model to explain explicit knowledge internalization}

According to the SECI model, tacit knowledge in the transformation into explicit knowledge works through a variety of ways to allow employees to learn, so as to achieve the function of knowledge dissemination [11]. In this process of transformation, acceptance of explicit knowledge is not the same, resulting in understanding of errors and bias. Because tacit knowledge and association are based on the staff's knowledge system and related experience, management consulting firms often use internal training activities to achieve the purpose of internal knowledge dissemination within the organization[12]. However, the staff cannot fully understand and accept these hard-won explicit knowledge due to the attenuation of information transmission and individual understanding of the difference between the degrees [13]. The link of company's early tacit knowledge and explicit knowledge is a blow between the two aspects of the work, as shown in Table 2.

Table 2. Effect matrix of the model under the hypothesis

\begin{tabular}{|l|l|l|l|l|}
\hline External variables & External variables & $\begin{array}{l}\text { load of } \\
\text { coefficients }\end{array}$ & $\begin{array}{l}\text { standard } \\
\text { error }\end{array}$ & t-value \\
\hline $\begin{array}{l}\text { knowledge } \\
\text { socialization }\end{array}$ & $\begin{array}{l}\text { growth of core } \\
\text { technical capacity }\end{array}$ & 0.32 & 0.07 & 3.99 \\
\hline $\begin{array}{l}\text { knowledge } \\
\text { socialization }\end{array}$ & $\begin{array}{l}\text { growth of core } \\
\text { management capacity }\end{array}$ & 0.36 & 0.08 & 2.87 \\
\hline $\begin{array}{l}\text { knowledge } \\
\text { socialization }\end{array}$ & $\begin{array}{l}\text { growth of core } \\
\text { marketing capacity }\end{array}$ & 0.39 & 0.08 & 1.51 \\
\hline $\begin{array}{l}\text { knowledge } \\
\text { explication }\end{array}$ & $\begin{array}{l}\text { growth of core } \\
\text { technical capacity }\end{array}$ & 0.43 & 0.12 & 5.43 \\
\hline $\begin{array}{l}\text { knowledge } \\
\text { explication }\end{array}$ & $\begin{array}{l}\text { growth of core } \\
\text { management capacity }\end{array}$ & 0.63 & 0.10 & 6.02 \\
\hline $\begin{array}{l}\text { knowledge } \\
\text { elicitation }\end{array}$ & $\begin{array}{l}\text { growth of core } \\
\text { marketing capacity }\end{array}$ & 0.67 & 0.09 & 6.19 \\
\hline $\begin{array}{l}\text { knowledge } \\
\text { combination }\end{array}$ & $\begin{array}{l}\text { growth of core } \\
\text { technical capacity }\end{array}$ & 0.70 & 0.08 & 2.66 \\
\hline $\begin{array}{l}\text { knowledge } \\
\text { combination }\end{array}$ & $\begin{array}{l}\text { growth of core } \\
\text { management capacity }\end{array}$ & 0.56 & 0.13 & 1.89 \\
\hline $\begin{array}{l}\text { knowledge } \\
\text { combination }\end{array}$ & $\begin{array}{l}\text { growth of core } \\
\text { marketing capacity }\end{array}$ & 0.60 & 0.11 & 1.65 \\
\hline
\end{tabular}

\section{Summary}

We need to continue to capture and accumulate the corresponding knowledge in the process, which is corresponding to the development of knowledge economy in the right direction. The application of the SECI model in the design innovation process is a critical step towards the right direction. The comparison between the design innovation model and the SECI model has the inspiration to the enterprise management and the design practice.

In addition, it is more difficult for the specialized personnel who are engaged in explicit knowledge to contribute to the knowledge of others. It is more difficult to incorporate it into the original knowledge system in the effect of explicit knowledge. Management company's tacit knowledge management is the existence of this problem, and the company has tried to establish a group interaction through the tacit knowledge of the dominant. Therefore, from the perspective of 
knowledge management, innovation process will be used to help us better understand the innovative tools. Product and service innovation at the same time help promote enterprise development in this way

For business practice, business managers realize that knowledge creation and design innovation are the core activities of enterprises. While the design of innovation or enterprise knowledge is aimed for the design practice, the designer gains the knowledge creation and knowledge management mechanism in-depth study, combined with the mastery of the design methods in order to develop the needs of knowledge-based economic development model.

\section{References}

[1] Nonaka I, Toyama R, Konno N. SECI, Ba and leadership: a unified model of dynamic knowledge creation[J]. Long range planning, 2000, 33(1): 5-34.

[2] Nonaka I, Toyama R. The knowledge-creating theory revisited: knowledge creation as a synthesizing process[J]. Knowledge management research \& practice, 2003, 1(1): 2-10.

[3] Desouza K C, Awazu Y. Knowledge management at SMEs: five peculiarities[J]. Journal of knowledge management, 2006, 10(1): 32-43.

[4] Seidler-de Alwis R, Hartmann E. The use of tacit knowledge within innovative companies: knowledge management in innovative enterprises[J]. Journal of knowledge Management, 2008, 12(1): 133-147.

[5] Bueren A, Schierholz R, Kolbe L M, et al. Improving performance of customer-processes with knowledge management[J]. Business Process Management Journal, 2005, 11(5): 573-588.

[6] Gebert H, Geib M, Kolbe L, et al. Towards customer knowledge management: Integrating customer relationship management and knowledge management concepts[C]//The Second International Conference on Electronic Business (ICEB 2002). 2002: 296-298.

[7] Li M, Gao F. Why Nonaka highlights tacit knowledge: a critical review[J]. Journal of knowledge management, 2003, 7(4): 6-14.

[8] Lin C, Tseng S M. The implementation gaps for the knowledge management system[J]. Industrial Management \& Data Systems, 2005, 105(2): 208-222.

[9] Xin G. The IDE-SECI Model of Knowledge Creation-An Extension to Nonaka's Self-transcendency Model [J][J]. Nankai Business Review, 2003, 5: 003.

[10]Nonaka I, Toyama R, Hirata T. Managing flow: A process theory of the knowledge-based firm[M]. Springer, 2008.

[11]Tong J, Mitra A. Chinese cultural influences on knowledge management practice[J]. Journal of knowledge management, 2009, 13(2): 49-62.

[12]Kakabadse N K, Kakabadse A, Kouzmin A. Reviewing the knowledge management literature: towards a taxonomy[J]. Journal of knowledge management, 2003, 7(4): 75-91.

[13]Chen Z, Xu X. Study on construction of knowledge management system based on enhancing core competence of industrial clusters[J]. International Journal of Business and Management, 2009, 5(3): 217. 